\title{
Arkiver fra hertugdømmerne Slesvig og Holsten indtil 1864 - nu i Landsarkivet for Sønderjylland
}

\author{
af HaNS SCHUltz HANSEN
}

I efteråret 2000 blev en række arkiver fra hertugdømmerne Slesvig og Holsten overflyttet fra Rigsarkivet i Kobenhavn til Landsarkivet for Sønderjylland i Aabenraa. Landsarkivar Hans Schultz Hansen fortæller her om disse arkiver og deres tilblivelse $i$ hertugdømmernes administration indtil 1864 - og om hvordan man finder rundt $i \mathrm{dem}$.

\section{Slesvig: Én region - mange hertugdømmer}

Fra omkring år 1200 udgjorde Sønderjylland et særligt hertugdømme med medlemmer af kongeslægtens yngre linjer som hertuger. Især efter 1241 voksede hertugernes selvstændighed i forhold til de danske konger. Samtidig vandt de holstenske grever betydelig indflydelse i Sønderjylland. Fra 1386 til 1459 var holstenske grever tilmed hertuger af Slesvig - som landsdelen fra nu af stadig oftere kaldtes.

I 1460 blev den danske konge valgt til hertug af Slesvig og til greve (fra 1474 hertug) af Holsten. Denne tilstand varede indtil afståelsen af begge hertugdømmer til Østrig og Preussen i 1864. Imidlertid udgjorde betydelige områder af Slesvig og Holsten efter de gentagne delinger i 1500- og 1600-tallet i lange perioder selvstændige småhertugdømmer. Navnlig delingen i 1544 trak lange spor efter sig. Hertugerne af Gottorp regerede over en del af Slesvig indtil 1713 og af Holsten indtil 1773. På Als og Ærø, på Sundeved og ved Glücksborg havde fra 1564 og indtil 1779 hertug Hans den Yngre og hans mange efterkommere deres bittesmå dele af Slesvig - hertugerne af Sønderborg, Nordborg, Ærø, Glücksborg og Plön. Dertil kom hertugerne af Augustenborg, uden eget hertugdømme, men efterhånden med store godser. 
De kongelige andele af Slesvig blev regeret fra København. Selv om de mange små hertugdømmer med tiden blev inddraget under kronen, beholdt hertugdømmerne som helhed alligevel indtil 1864 en særstilling i den kongelige administration. Fra 1523 til 1848/49 blev landene regeret fra det Tyske Kancellis Indenrigske Afdeling i København via kongens statholder $i$ hertugdømmerne og de lokale regeringer i Glückstadt og Slesvig.

Treårskrigen 1848-50 skabte et opbrud i dette mønster. Under krigen fungerede en række kortvarige regeringer. Efter 1850 skete der en forenkling. De lokale regeringer forsvandt, og centraladministrationen blev delt med indførelsen af Ministeriet for hertugdømmet Slesvig og et tilsvarende ministerium for Holsten og Lauenborg.

\section{Arkiverne og deres brug}

De mange hertuger, kancellier og ministerier i København, statholderen og de lokale regeringer har alle efterladt sig mere eller mindre velbevarede arkiver, som i dag udgør hovedkilder til hertugdømmernes historie før 1864. Efter grænsedragningerne i 1864 og 1920 blev de fleste af dem delt mellem Danmark og Tyskland og opbevaret i Kiel (senere i Slesvig) og i København. Delingen af arkiverne medførte, at de danske og de tyske dele blev ordnet og fortegnet efter forskellige principper. Delingen har længe vanskeliggjort benyttelsen af arkiverne. For at fremme brugen af den danske del af arkiverne til udforskningen af de gamle hertugdømmers historie og som en håndsrækning navnlig til den slesvig-holstenske historieforskning, blev en række af arkiverne i 2000 efter beslutning i Statens Arkivers ledelse overført fra Rigsarkivet i København til Landsarkivet for Sønderjylland i Aabenraa - enten i original eller som mikrofilm. Dermed kom de meget tættere på de tyske dele af de samme arkiver i Slesvig, hvilket letter benyttelsen meget. I det følgende vil de vigtigste arkivgrupper blive nærmere præsenteret.

\section{De sønderjyske fyrstearkiver}

De mange sønderjyske hertuger er for længst en saga blot, men deres arkiver består. De originale arkivalier opbevares stadig på Rigsarkivet i København, men Landsarkivet for Sønderjylland har fået mikrofilm af sagerne på papir. Pergamentsdokumenterne må derimod fortsat 


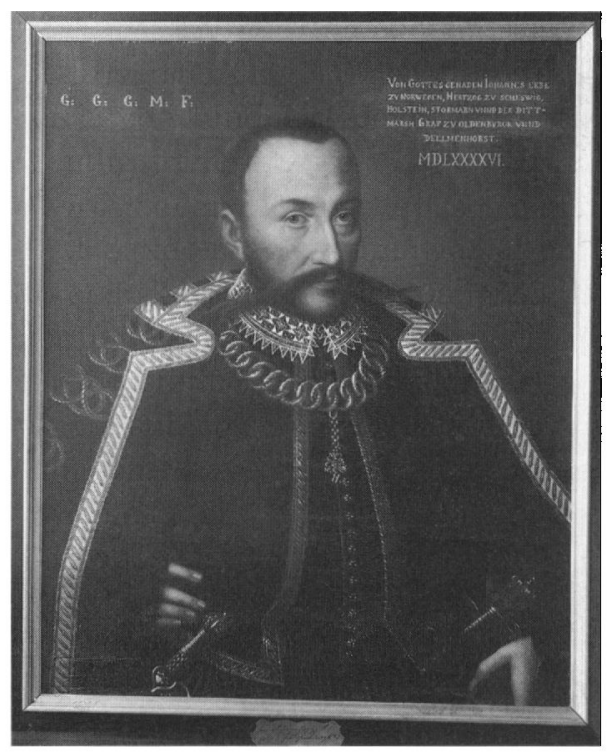

Hans den Yngre (1545-1622), hertug af Slesvig-Holsten-Sønderborg, blev stamfader til de mange sønderborgske hertuglinjer. Her ses han afbildet på et maleri fra 1596, der hænger på Glücksborg Slot. Forkortelsen G.G.G.M.F. stär for det fromme onske: Gott gebe Glück mit Frieden. Efter foto i Institut for sønderjysk Lokalhistorie.

benyttes på Rigsarkivet. En betydelig del af dem foreligger imidlertid trykt. Det gælder navnlig pergamenterne fra de ældste hertugers tid.

De arkiver, som Landsarkivet nu har mikrofilm af, er for middelalderens vedkommende: Hertugerne af Sønderjylland af Abels slægt 1269-1386, de schauenburgske hertuger af Sønderjylland og grever af Holsten 1260-1460, grev Gerhard af Oldenburg 1454-70, hertug Frederik (1.) 1483-1523 og hertug Christian (3.) 1523-1534.

Ved delingen i 1544 blev der ud over den kongelige del oprettet to selvstændige hertugdømmer: Haderslev og Gottorp. Hertug Hans den Ældres arkiv, også kaldet Hansborgarkivet, omfatter arkivalier fra årene 1460-1587. De gottorpske hertugers arkiver - Gottorparkivet - har akter fra årene 1328-1714. Derudover findes Fællesarkivet - Gemeinschaftliches Archiv 1542-1643, som var et fælles arkiv for de regerende fyrster efter delingen i 1544, og arkivet fra hertug Frederik, biskop af Slesvig og Hildesheim 1544-1553, der ikke fik en del af hertugdømmerne, men i stedet en gejstlig karriere. Alle nævnte arkiver findes nu på mikrofilm i landsarkivet.

I 1564 blev kong Frederik 1.s yngre bror, hertug Hans den Yngre, tildelt en bid af den kongelige del. Han blev dog ikke regerende fyrste, men "afdelt herre". Hans område blev Als og Sundeved, fra 1571 tillige Glücksborg og Plön. Landsarkivet har mikrofilm af Hans den 
Yngres arkiv, og det samme gælder arkiverne fra de mange små hertugdømmer, der opstod ved arvedelingen efter hans død i 1622: Hertugdømmet Arø 1627-40, hertugdømmet Sønderborg 1619-1668 med tillæg: Augustenborg 1667-1816, hertugdømmet Nordborg 1649-1650, hertugdømmet Glücksborg 1502-1779 samt hertugdommet Plön 1625-1729 (Plön, Plön-Nordborg og Plön-Søbygård).

De sønderjyske fyrstearkiver er alle registreret i Erik Kroman: De sønderjyske Fyrstearkiver (Vejledende Arkivregistraturer X), Kbh. 1959. Landesarchiv Schleswig-Holstein har betydelige dele af de ovennævnte arkiver, navnlig Gottorparkivet, se herom Kurt Hector: Findbuch des Bestandes Abt. 7, Herzöge von Schleswig-Holstein-Gottorf 15441713, I-III. Slesvig 1977-83. Her findes også hovedparten af de plönske hertugers arkiver (Abt. 20) samt det augustenborgske husarkiv "Primkenauarkivet« - (Abt. 22). Godsarkiverne fra de augustenborgske hertuger findes derimod i Landsarkivet for Sønderjylland, se fortegnelsen De augustenborgske og gråstenske godser, Aabenraa 1978.

\section{Tyske Kancellis Indenrigske Afdeling}

De kongelige dele af hertugdømmerne blev siden 1523 administreret af Tyske Kancellis Indenrigske Afdeling i Kobenhavn. Ved opløsningen af Det tyske Rige og indlemmelsen af Holsten i det danske monarki i 1806 ændredes navnet til Slesvig-Holstenske Kancelli og ved indlemmelsen af Lauenborg i 1816 til Slesvig-Holsten-Lauenborgske Kancelli. Dette navn beholdt kancelliet indtil ophævelsen i 1849.

Den danske del af arkivet er underinddelt i perioderne 1523-1670, 1670-1770 og 1770-1849 samt $i$ en saggruppeordnet del omfattende perioden efter 1730, som igen er delt $i$ en almindelig og en topografisk afdeling. Grundstammen i arkivet er de to rækker af brevkopibøger. Rækken med Patenten består af de såkaldte åbne breve med alment indhold beregnet til kundgørelse, mens Inländische Registratur rummer de lukkede breve, som blev stilet til en enkelt person eller en begrænset personkreds. Dertil kommer fra 1770 protokollerne med Vorstellungen, d.v.s. kancelliets indstilling til kongen i de enkelte sager med anførelse af majestætens beslutning.

En grundig oversigt over arkivets historie findes i Johanne Skovgaard: Tyske Kancelli I (Vejledende arkivregistraturer VII), Kbh. 1946. Her findes tillige en udførlig fortegnelse over den danske del af arkivet, der befinder sig i original på Rigsarkivet, mens mikrofilm af arkivet er 


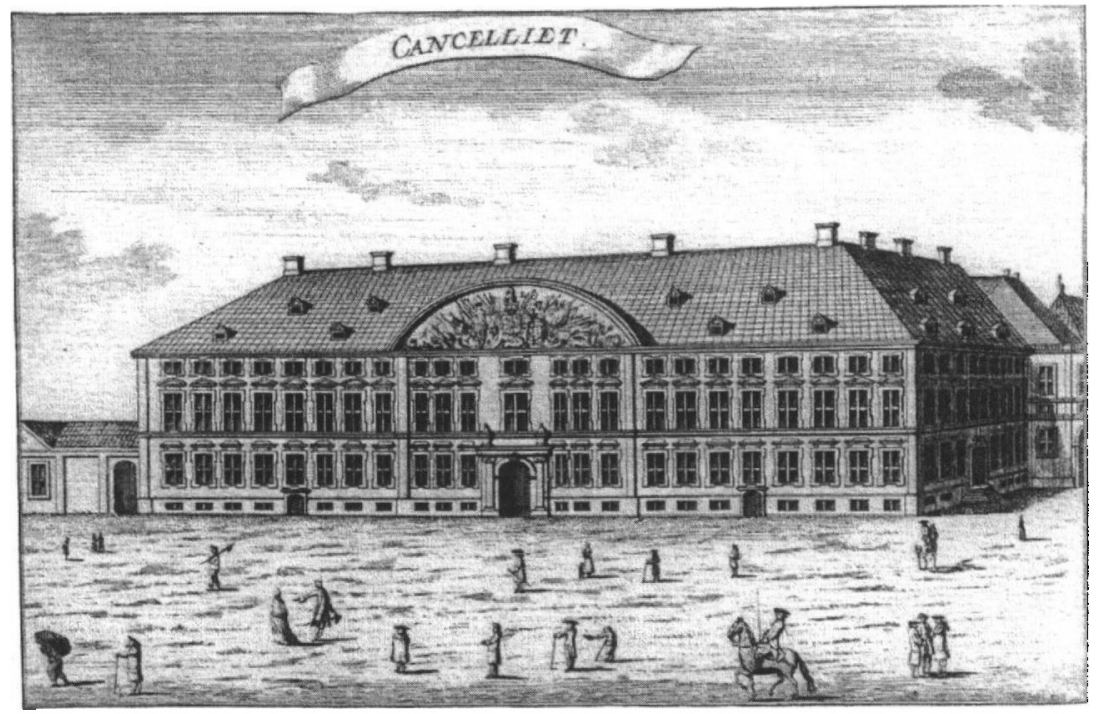

Kancellibygningen, også kaldt "Den rode bygning", $i$ Kobenhavn blev opført $i 1720$ og har siden huset den danske centraladministration - selv om den umuligt kan rumme alle kontorerne fra nutidens ekspanderende bureaukrati. I helstatstiden havde Tyske Kancelli til huse her. Stik fra omkring 1740 i Det kongelige Bibliotek.

overført til Landsarkivet for Sønderjylland. På landsarkivets læsesal findes filmlister. Hovedparten af arkivet befinder sig imidlertid i dag i Landesarchiv Schleswig-Holstein som Abt. 65, der er delt i Abt. 65.1, tiden indtil 1730, og 65.2, årene 1730-1849. Over den første del findes en fortegnelse ved Konrad Wenn: Deutsche Kanzlei zu Kopenhagen bis 1730, Slesvig 1981. Til den anden del må benyttes håndskrevne fortegnelser, der findes i kopi på læsesalen i Slesvig. Det er hovedsagelig akterne efter 1730, som befinder sig i Slesvig.

\section{Finansarkiver}

Mikrofilm af Rigsarkivets forskellige samlinger af slesvigske regnskaber befinder sig nu på Landsarkivet for Sønderjylland. Det er især amtsregnskaber og jordebøger fra 1438 til 1864.

Rentekammeret i København svarede under enevælden til senere tiders finans-, økonomi-, erhvervs- og landbrugsministerier. Det havde en særlig Tysk Afdeling, som styrede hertugdømmernes finansielle forhold. Arkivet herfra er delt mellem Danmark og Tyskland. Den 
danske del opbevares på Rigsarkivet og er fortegnet i en maskinskrevet registratur, hvoraf et eksemplar findes på Landsarkivet for Sønderjylland. På landsarkivet findes mikrofilm af forestillingsprotokoller, resolutioner og reskripter samt af akter fra undersøgelseskommissionen i Haderslev amt 1708-15. Benyttelsen sker på grundlag af maskinskrevne filmlister. Den tyske del udgør Abt. 66 i Landesarchiv Schleswig-Holstein og er registreret i W. Prange og K. Wenn: Rentekammer zu Kopenhagen 1-3, Slesvig 1993.

\section{Hertugdømmernes provinsforvaltning indtil 1848}

Mellem den lokale kongelige amtsforvaltning i hertugdømmerne og Tyske Kancellis Indenrigske Afdeling i Kobenhavn fandtes der flere melleminstanser med sæde i hertugdømmerne. Om dem alle gælder, at deres efterladte arkiver er delt mellem Danmark og Tyskland. De danske dele er fortegnet i Johanne Skovgaard: Tyske Kancelli I, Kbh. 1946, s. 101-164.

I 1545 indsatte kongen første gang en statholder til at varetage sine interesser i hertugdømmerne. Embedet bestod med mindre afbrydelser indtil 1848. Den danske del findes nu på Landsarkivet for Sønderjylland. Den tyske del udgør Abt. 10 i Landesarchiv SchleswigHolstein.

I 1648 oprettede Christian 4. et særligt regeringskancelli for de kongelige dele af hertugdømmerne under forsæde af statholderen. Det fik sæde i Glückstadt og var tillige appeldomstol. Fra 1713 beskæftigede kancelliet sig kun med holstenske forhold. Den danske del af arkivet befinder sig fortsat på Rigsarkivet, men Landsarkivet for Sønderjylland har fotokopier af den topografisk ordnede afdelings sager vedr. Nordslesvig. Den tyske del udgør Abt. 11 i Landesarchiv.

Da de gottorpske hertuger blev fordrevet fra Slesvig i 1713, blev Overretten på Gottorp oprettet som kongelig regering og appeldomstol for dette hertugdømme alene. Den danske del findes på landsarkivet i Aabenraa. Den tyske del udgør Abt. 13 i Landesarchiv. Sammen med arkivet fra Overretten hører arkivet fra Overkonsistoriet for hertugdømmet Slesvig. Denne myndighed bestod af Overrettens embedsmænd suppleret med den slesvigske generalsuperintendent og de tre ældste provster i Slesvig stift. Arkivet indeholder kirke- og skolesager og er delt mellem Aabenraa og Slesvig.

Samtidig med indførelsen af stænderforsamlingerne for Slesvig og 


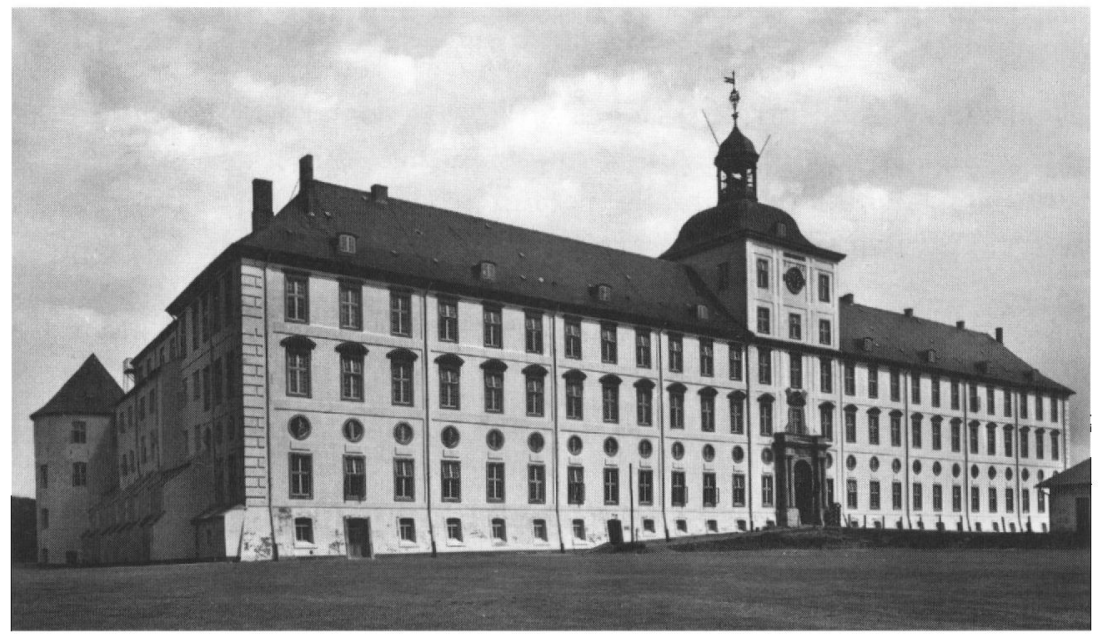

Gottorp Slot ved Slesvig var gennem århundreder et centrum i hertugdommernes administration. Det var fra 1544 sæde for de gottorpske hertuger og fra 1713 for Overretten på Gottorp med Overkonsistoriet for hertugdømmet Slesvig. Ogsd den slesvig-holstenske provinsialregering havde fra oprettelsen $i 1834$ sine lokaler her. Postkort $i$ Institut for sønderjysk Lokalhistorie.

Holsten blev der i 1834 oprettet en fælles regering for de to hertugdømmer på Gottorp. Den overtog forvaltningen fra Regeringskancelliet og Overretten, der herefter udelukkende fortsatte som appeldomstole. Den danske del af arkivet findes nu i Aabenraa. Den tyske del udgør Abt. 49 i Landesarchiv Schleswig-Holstein.

Blandt de øvrige arkiver fra provinsadministrationen, som nu er overført til Landsarkivet for Sønderjylland, kan nævnes Censor i Kiel, Fr. Carl Clausewitz' embedsarkiv 1819-31, der rummer en pakke med censurprotokoller og korrespondance, og Kommissionen til udbredelse af den indbyrdes undervisning i hertugdømmerne 1829-1849.

Endvidere findes nu på landsarkivet en række helt små arkivfragmenter fra Landretten, Generalkrigskommissæren i Slesvig, Landskabet Nordstrand, Gottorp provsti, Sørup og Adelby sognekald, Flensborg latinskole, Medicinalinspektoratet for hertugdømmet Slesvig og fysikatet i Tønder, Ejdersted og Nordstrand, enkelte sager fra flere amts- og byarkiver. Indholdet af disse små arkiver er beskrevet i Rigsarkivet og hjælpemidlerne til dets benyttelse, I, Kbh. 1983, s. 297-299 samt i en maskinskrevet fortegnelse på Landsarkivet. 


\section{Myndigheder under revolutionstiden 1848-51}

Under den slesvig-holstenske opstand og Treårskrigen blev der oprettet forskellige midlertidige regeringsmyndigheder. Også her er arkiverne i flere tilfælde delt mellem Danmark og Tyskland, og de danske dele er nu overført til landsarkivet i Aabenraa. En oversigt over de danske dele af arkiverne findes i Rigsarkivet og hjælpemidlerne til dets benyttelse, II, Kbh. 1991, s. 459-465 og s. 1880-1883. Landsarkivet har kopi af ældre seddelregistraturer.

Den provisoriske regering $i$ Kiel 1848 blev dannet 24 . marts 1848 af førende slesvig-holstenere, men allerede ophævet 22. oktober samme år. Den danske del indeholder kun nogle regnskabssager. Hovedparten befinder sig på Landesarchiv Schleswig-Holstein i Abt. 22 og Abt. 51.

På dansk side blev Regeringskommissionen for Hertugdømmet Slesvig nedsat den 4 . april 1848 til at bestyre den del af Slesvig, som de danske tropper havde magt over. Den blev ophævet 31. marts 1849. Næsten samtidigt blev Undersøgelseskommissionen for Hertugdømmet Slesvig dannet med henblik på undersøgelse af de slesvigske embedsmænds stilling til den provisoriske regering. Immediatkommissionen/ Overbestyrelseskommissionen for Als og Ærø blev oprettet 18. september 1848 som regering for hele Slesvig, men fik reelt kun myndighed over Als og Ærø, der holdtes besat af de danske tropper. Den blev ophævet i november 1849. Toldsager findes i Landesarchiv Schleswig-Holstein Abt. 52.

I sommeren 1849 blev der efter en dansk-preussisk våbenhvile indsat en dansk-preussisk-britisk bestyrelseskommission. Den påbegyndte sin virksomhed den 25. august 1849 og regerede Slesvig indtil den 13. juli 1850. Det danske medlem fungerede videre som overordentlig regeringskommissær indtil 5. marts 1851 . Dette arkiv opbevares også fremover $\mathrm{i}$ original på Rigsarkivet, men mikrofilm vil snart tilgå Landsarkivet for Sønderjylland. Toldsager findes i Landesarchiv Schleswig-Holstein Abt. 53.

\section{Ministeriet for Hertugdømmet Slesvig og andre myndigheder 1851-1864}

Efter Treårskrigen samledes centraladministrationen af Slesvig i 1851 i Ministeriet for Hertugdømmet Slesvig med sæde i København. Den 


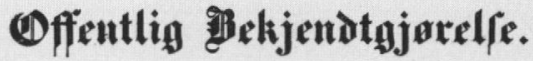

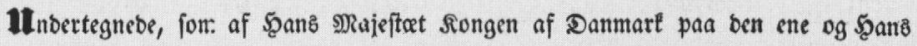

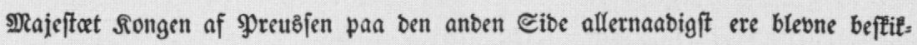

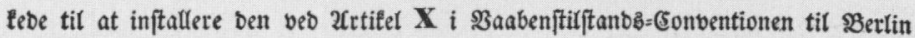

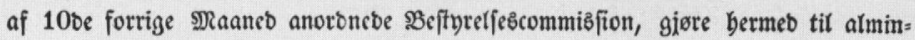
belig Efterretning og Efterlebelfe vittcrligt:

at til at ubgiøre benne Commișfion cre blevne ubjecte fra אongelig Danft

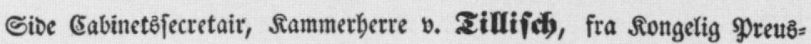

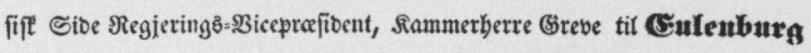

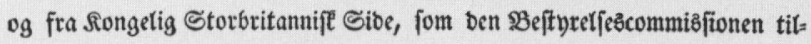
fororonebe spmant, sberft og Chargé d'affaires \$obges, og at

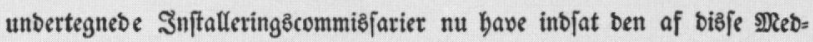

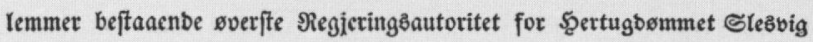

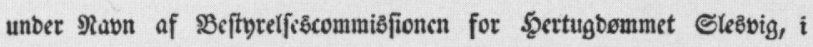
benz Embebe, til fra ibag af unber Baabenftilftanben $i$ ફans sRajeftet

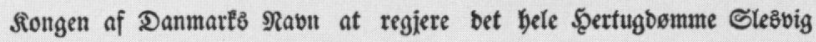
meb ben famme ifølge ben obennpronte Baabenftilftanbs = Conbentions $\mathfrak{a t}=$

tiel $\mathbf{X}$ tilfommente mennoigheb.

Flenţorg ben 25. Xuguft 1849.

\section{Pechlin.}

Blandt de mange regeringer fra Treårskrigens tid var den dansk-preussisk-engelske bestyrelseskommission, som tiltrådte $i$ august 1849 og fungerede $i$ næsten et år indtil midten af juli 1850. Den offentlige bekendtgørelse viser, at kongerne af Danmark og Preussen stod bag, men modsat de svensk-norske tropper $i$ Nordslesvig og de danske på Als-Arø viste de preussiske besættelsestropper $i$ Sydslesvig sig at være en upålidelig magtbasis. Oprảb i Immediatkommissionens arkiv. 
særlige provinsadministration blev samtidig ophævet. Ministeriets arkiv befinder sig på Rigsarkivet i København, se Rigsarkivet og hjælpemidlerne til dets benyttelse, II, s. 459-476. Endvidere er der udarbejdet en Generalregistratur, der bl.a. findes i kopi på Landsarkivet. Landsarkivet for Sønderjylland har mikrofilm af forordninger, forestillinger, journaler, journalregistre og forskellige enkeltsager, se maskinskrevet filmliste på landsarkivet. En betydelig del af arkivet befinder sig i Landesarchiv Schleswig-Holstein, Abt. 79.

På tilsvarende vis blev der i 1852 oprettet et Ministerium for Hertugdømmerne Holsten og Lauenborg. Langt størstedelen af dette arkiv opbevares på Landesarchiv Schleswig-Holstein, Abt. 80. På Rigsarkivet findes forestillingsprotokoller og visse personalesager m.m., se Rigsarkivet og hjælpemidlerne til dets benyttelse, II, s. 476-478. På Landsarkivet for Sønderjylland findes mikrofilm af forestillingsprotokollerne og af beretninger om forholdene 1863-64, se maskinskrevet filmliste.

Blandt de andre arkiver fra tiden mellem de slesvigske krige findes nu i landsarkivet i Aabenraa: Regnskaber vedr. de tyske forbundstropper i Slesvig 1849, Centralkassen for Hertugdømmet Slesvig 184964, Den Kongelige Kommissarius for Stænderforsamlingen i Hertugdømmet Slesvig 1853-63 samt Oversagføreren for Hertugdømmet Slesvig (sager vedr. Højer Forland og Ny Frederikskog 1861-68). Oversigter over disse arkiver findes i Rigsarkivet og hjælpemidlerne til dets benyttelse, II, s. 1883-86.

\section{Forskningsmuligheder}

Kun fantasien sætter grænser for, hvad arkiverne fra central- og provinsforvaltningen for hertugdømmerne Slesvig og Holsten indtil 1864 kan bruges til. Det har imidlertid været en særlig hensigt med flytningen til Aabenraa at fremme studierne i det gamle hertugdømme Slesvigs omskiftelige historie. Tiden er navnlig kommet til en fordomsfri vurdering af hertugdømmets - og de mange hertugdømmers styreformer - frigjort fra det 19. og 20. århundredes nationalpolitiske problemstillinger. Gennem administrationshistoriske studier kan det belyses, i hvilken udstrækning hertugdømmet var selvstyrende. Det er klart, at sådanne undersøgelser også må inddrage de andre arkiver i landsarkiverne nord og syd for grænsen; her tænkes navnlig på arkiverne fra amter, landskaber, godser og købstæder. 
Men også til den økonomiske og sociale udvikling og kirke- og skolehistorien rummer arkiverne fra hertugdømmernes central- og provinsforvaltning et stort stof. Sidst, men ikke mindst, udgør arkiverne et vigtigt materiale for lokalhistorikerne. 